\title{
Influence of the General Control of Amino Acid Biosynthesis on Cell Growth and Cell Viability in Saccharomyces cerevisiae
}

\author{
By P. NIEDERBERGER,* M. AEBI AND R. HÜTTER \\ Mikrobiologisches Institut, Eidgenössische Technische Hochschule, ETH-Zentrum, \\ CH-8092, Zürich, Switzerland
}

(Received 7 December 1982; revised 14 February 1983)

\begin{abstract}
The general control of amino acid biosynthesis was shown to play an important role in the coordination between cell growth and cell division under amino acid limitations. Mutant strains defective in this regulatory system, as studied here mainly with mutant strain RH375 (ndrl-1), showed excessive and aberrant cell growth under mild limitation, and rapid loss of cell viability under severe amino acid limitation. Furthermore, wild-type (NDRI) cells were able to derepress, or at least maintain, levels of enzymes subject to the general control under amino acid limitations. The ndrl-1 mutant cells showed significantly decreased enzyme levels under these conditions. The loss of viability of $n d r 1-1$ mutant cells was not due to inability to accumulate at 'Start' under amino acid limitation. In conclusion, we postulate that the aberrant behaviour of $n d r$-mutant cells is due to an inability to maintain adequate levels of amino acid biosynthetic enzymes throughout the mitotic cell cycle.
\end{abstract}

\section{INTRODUCTION}

Yeast cells are able to synthesize all precursors necessary for their macromolecular components such as DNA, RNA and protein from basic nutrients such as glucose, ammonia, inorganic phosphate and sulphate. In general, however, organic precursors, e.g. amino acids, are provided by the environment, although in variable and often imbalanced amounts, e.g. in grape musts (Amerine \& Ough, 1980). Regulatory mechanisms have thus evolved to curtail the cell's own amino acid synthesis in response to external amino acid supply (Niederberger et al., 1981), since uptake is energetically more favourable (Brenner \& Ames, 1971).

In Saccharomyces cerevisiae as in other eukaryotic fungi, e.g. Neurospora crassa (Carsiotis \& Jones, 1974) or Aspergillus nidulans (Piotrowska, 1980), a regulatory mechanism called the 'general control of amino acid biosynthesis' (Delforge et al., 1975) has been found to co-regulate the synthesis of a number of enzymes of branched pathways of amino acid biosynthesis and of the basic amino acid biosynthetic pathways. This was demonstrated with the help of regulatory mutant strains defective in genes $N D R 1, N D R 2$ (allelic to $A A S 1$ ), and $A A S 2$ (Niederberger $e t$ al., 1981; Wolfner et al., 1975). These mutant strains are unable to derepress enzymes under the general control and grow considerably slower than wild-type cells under amino acid limitation, induced by amino acid analogues (Schürch et al., 1974), bradytrophic mutations or external amino acid imbalance (Niederberger et al., 1981). It was proposed that the general control is important in the maintenance of an adequate supply of each amino acid.

Wolfner et al. (1975) have isolated a mutant strain defective in a regulatory gene, TRA3, which at the same time was constitutively derepressed for enzymes under the general control and led to G1-arrest at elevated temperature. They proposed, therefore, that mechanisms must exist to coordinate cell proliferation with the availability of essential inorganic and organic nutrients. Upon starvation for a number of basic nutrients, $S$. cerevisiae cells accumulate in the G1-phase of the mitotic cycle as unbudded cells at a point called 'Start' (for review see Pringle \& Hartwell, 1981). Much less is known about the influence of limitations for organic nutrients such as amino 
acids. Unger \& Hartwell (1976) have shown that $S$. cerevisiae also accumulates at Start during deprivation of charged tRNA ${ }^{\text {Met }}$ and have proposed a signal at the level of protein synthesis to be involved. Shilo et al. (1978) found about $80 \%$ unbudded cells after starvation for methionine or histidine.

In this work, we undertook a systematic study of the influence of amino acid limitation on cell growth and division. We show that there exists a fundamental difference between limitations for basic nutrients and for amino acids (or charged tRNA) since cells grew bigger in the latter case, rather than smaller. Mutation $n d r l-1$ is found to have two major effects: first, it leads to uncoordination between cell growth and cell division under mild amino acid limitations, and thereby much bigger cells with shmoo-like morphology may occur (Bücking-Throm et al., 1973); secondly, it leads to a faster loss of cell viability under severe amino acid limitations.

\section{METHODS}

Organisms. Saccharomyces cerevisiae wild-type strain X2180-1A a was obtained from T. Manney, Manhattan, Kansas, U.S.A. The bradytrophic (leaky auxotrophic) strains were isolated as described previously (Niederberger et al., 1981). The non-derepressing (Ndr) regulatory mutant strain RH375 (ndrl-1) arose as a 5-methyltryptophansensitive mutant strain from strain X2180-1A after mutagenesis with $N$-methyl- $N^{\prime}$-nitro- $N$-nitrosoguanidine (Schürch et al., 1974). The other Ndr-mutant strains RH428 (ndr 1-2) and RH487 (ndr2-1) have also been described earlier (Schürch et al., 1974). Strain 4298-9C (aas2) was kindly provided by G. Fink, Cornell University, Ithaca, New York, U.S.A. Strain RH700 carrying mutation ils 1 - 1 (leading to a temperature-sensitive isoleucyl-tRNA synthase; McLaughlin et al., 1979), was derived from strain $t s 341$ (obtained from the Yeast Genetic Stock Center, University of California, Berkeley, CA, U.S.A.) by two backcrosses with strain X2180-1A. All double-mutant strains carrying bradytrophic, auxotrophic (leu2-2) or temperature-sensitive (ils1-1) mutations in addition to mutation $n d r l-1$ (or other $n d r$ mutations) were constructed by crosses ('spore en masse' technique, Fowell, 1966; or tetrad dissection, Johnston \& Mortimer, 1959). They were identified as being both 5-methyltryptophan-sensitive and partly or completely deficient for a particular amino acid, or being temperature-sensitive.

Media and growth conditions. Minimal medium MV [0.145\% (w/v) Difco yeast nitrogen base, $0.525 \%(\mathrm{w} / \mathrm{v})$ ammonium sulphate, $2 \%(\mathrm{w} / \mathrm{v})$ glucose] was buffered to $\mathrm{pH} 4.0$ with $1 \%(\mathrm{w} / \mathrm{v})$ succinic acid and $0 \cdot 28 \%(\mathrm{w} / \mathrm{v})$ potassium hydroxide. L-Amino acids were filter-sterilized and added to the medium before use at concentrations as indicated in the text. Nitrogen-free MV-medium was prepared as described above but ammonium sulphate was omitted. YEPD-agar [ $2 \%(\mathrm{w} / \mathrm{v})$ Oxoid peptone, $1 \%(\mathrm{w} / \mathrm{v})$ Oxoid yeast extract, $2 \%(\mathrm{w} / \mathrm{v})$ glucose, $2 \%(\mathrm{w} / \mathrm{v})$ Bacto agar] was used for determination of viable cell number (see below). For all experiments, exponentially growing cells (viable cell count approx. $1 \times 10^{7} \mathrm{ml}^{-1}$ ) were used. The cells were cultivated in baffled Erlenmeyer flasks (four indentations) to provide adequate aeration, and incubated at $30^{\circ} \mathrm{C}$ on a rotary shaker. Exceptions were strains $\mathrm{RH} 700$ and $\mathrm{RH} 701$, which were shaken in rotary water baths at $23^{\circ} \mathrm{C}, 34^{\circ} \mathrm{C}$, or $37^{\circ} \mathrm{C}$.

Measurement of cell growth parameters. Turbidity was determined in a Beckman 24 spectrophotometer at $546 \mathrm{~nm}$ with a $1 \mathrm{~cm}$ light path. All values were corrected for linearity after the method of Bestic \& Arnold (1976). Dry weight was determined from $100 \mathrm{ml}$ of cell culture. The cells were harvested on pre-weighed Millipore filters (HAWP 047SO; $0.45 \mu \mathrm{m}$ pore size), washed twice with $10 \mathrm{ml}$ ice-cold water and dried to constant weight at $70^{\circ} \mathrm{C}$ for at least $24 \mathrm{~h}$. For extraction of RNA and DNA, $200 \mathrm{ml}$ cultures were harvested on the same Millipore filters, washed twice with $10 \mathrm{ml}$ ice-cold water and twice with ice-cold $0.25 \mathrm{M}-\mathrm{HClO}_{4}$. The cells at this stage were stored frozen at $-80^{\circ} \mathrm{C}$ on the filters. RNA and DNA in the samples was determined by the procedure of Stewart (1975). The cells were washed off the filters with a total volume of $20 \mathrm{ml} 0.25 \mathrm{M}-\mathrm{HClO}_{4}$ and the suspension was left for $15 \mathrm{~min}$ on ice. This procedure was repeated once with centrifugation steps in between and after; each time the supernatant was discarded. $\mathrm{HClO}_{4}(0.5 \mathrm{M} ; 2 \mathrm{ml})$ was added and the suspension was incubated at $37{ }^{\circ} \mathrm{C}$ for $2 \mathrm{~h}$. After centrifugation, the supernatant was transferred to a graduated centrifuge tube. The sediment was washed once with $2 \mathrm{ml} 0.5 \mathrm{M}-\mathrm{HClO}_{4}$ and after centrifugation both supernatants were pooled in the graduated centrifuge tube. The hydrolysed RNA solution in this tube was made up to $5 \mathrm{ml}$ and stored for RNA determination. The cell sediment was resuspended in $1 \mathrm{ml} 0.5 \mathrm{M}-\mathrm{HClO}_{4}$ and incubated at $70^{\circ} \mathrm{C}$ for $15 \mathrm{~min}$. After centrifugation, the supernatant was transferred to a graduated centrifuge tube. The same extraction procedure was repeated twice and the pooled supernatants made up to $5 \mathrm{ml}$ and stored for DNA determination. RNA was determined in duplicate samples from $0.3 \mathrm{ml}$ of extract (diluted to about $100 \mu \mathrm{g} \mathrm{RNA} \mathrm{ml}{ }^{-1}$ ) mixed with $0.5 \mathrm{ml}$ orcinol reagent [1 vol. $1 \%(\mathrm{w} / \mathrm{v})$ orcinol solution mixed with 4 vol. $0.09 \%(\mathrm{w} / \mathrm{v}) \mathrm{FeCl}_{3} .6 \mathrm{H}_{2} \mathrm{O}$ in conc. $\mathrm{HCl}$. After boiling for $20 \mathrm{~min}$ and cooling to room temperature, $\mathrm{n}$-butanol $(2 \mathrm{ml})$ was added. Absorbance was read at $670 \mathrm{~nm}$. As a standard, soluble RNA from yeast (Sigma; 25 to $200 \mu \mathrm{g}$ ) was used. DNA was determined in duplicate samples from $2 \mathrm{ml}$ of extract mixed with $0.4 \mathrm{ml}$ conc. $\mathrm{HClO}_{4}$ and $1.6 \mathrm{ml}$ of diphenylamine reagent $[4 \%(\mathrm{w} / \mathrm{v})$ diphenylamine in glacial acetic acid in $0.01 \%(\mathrm{v} / \mathrm{v})$ paraldehyde]. Colour was developed for at least $20 \mathrm{~h}$ at room temperature in the dark. 
Absorbance was read at $600 \mathrm{~nm}$ against a reagent blank. As a standard, calf thymus DNA (sodium sait; Fluka, Buchs, Switzerland; 10 to $80 \mu \mathrm{g}$ ) was used. Protein was determined according to a procedure described by Johnston et al. (1977), which was modified as follows: $1 \mathrm{ml}$ of the cell culture was mixed with $5 \mathrm{ml}$ of $5 \%$ (w/v) TCA and kept on ice for $30 \mathrm{~min}$. After centrifugation, the supernatant was discarded, the pellet resuspended in $2 \mathrm{ml} \mathrm{95 \% (v/v)} \mathrm{ethanol} \mathrm{and} \mathrm{the} \mathrm{cells} \mathrm{centrifuged} \mathrm{again.} \mathrm{The} \mathrm{pellet} \mathrm{was} \mathrm{extracted} \mathrm{for} 5$ min by boiling in $0.5 \mathrm{M}-$ $\mathrm{NaOH}$ (see Herbert et al., 1971); $2.5 \mathrm{ml}$ of $\mathrm{CuSO}_{4}$-tartrate reagent $\left[1\right.$ part $12.5 \%(\mathrm{w} / \mathrm{v}) \mathrm{CuSO}_{4} .5 \mathrm{H}_{2} \mathrm{O}$ in 25 parts $1 \%(\mathrm{w} / \mathrm{v})$ potassium sodium tartrate; 1 part of this solution in 25 parts $5 \%(\mathrm{w} / \mathrm{v}) \mathrm{Na}_{2} \mathrm{CO}_{3}$ ] was then added and the mixture left for $10 \mathrm{~min}$ at room temperature. Folin-Ciocalteu reagent $\left(0.5 \mathrm{ml}\right.$, diluted $\left.1: 1 \mathrm{in} \mathrm{H}_{2} \mathrm{O}\right)$ were added and absorbance was determined at $500 \mathrm{~nm}$ after $30 \mathrm{~min}$. As a standard, BSA (20 to $75 \mu \mathrm{g}$ ) was used.

Measurement of cell division and budding. For determination of viable and total cell numbers and of budding degree, samples were mildly sonicated with a MSE $150 \mathrm{~W}$ ultrasonic disintegrator (microtip ethanol sterilized; amplitude $14 \mu \mathrm{m}$; sonication time $15 \mathrm{~s}$ with ice cooling) to destroy cell clumps. Viable cell number was determined after appropriate dilution in distilled water and triplicate platings were made on YEPD-agar. Colonies were scored after 2 to $5 \mathrm{~d}$. Total cell number was determined with a Celloscope 302 haemocytometer (AB Lars Ljungberg, Stockholm, Sweden; aperture diameter $48 \mu \mathrm{m}$; settings: aperture current, 8; multiplier, 1/4; discriminator, 14). Cells were fixed in equal volumes of formalin $[4 \%(\mathrm{v} / \mathrm{v})$ in $0 \cdot 15 \mathrm{M}-\mathrm{NaCl}]$ before counting. The degree of budding was determined with formalin-fixed, sonicated cells as described above. Between 200 and 300 cells were classified under the microscope for each determination.

Photomicroscopy. Cells growing in liquid MV-medium were mildly sonicated as described above and spread immediately on Nobel agar squares [Difco; $20 \%(\mathrm{w} / \mathrm{v})$; about $1 \mathrm{~mm}$ thick] mounted on glass slides. Cells were allowed to settle and dry for $1 \mathrm{~min}$ and a cover slip put on top. Photomicrographs were taken with a Zeiss-Photomicroscope III on Ilford FP4 films.

Enzyme assays. Indole-3-glycerol-phosphate synthase [1-(2'-carboxyphenylamino)-1-deoxyribulose-5-phosphate carboxy-lyase (cyclizing), EC 4.1.1.48] was determined in Triton X-100-permeabilized cells as described previously (Miozzari et al., 1978a,b).

\section{RESULTS}

\section{Influence of the general control on cell division, cell growth and macromolecular synthesis}

We have shown that mutation ndrl-1 leads to slower growth rates during conditions of limitation of several amino acids, whether induced by bradytrophic mutations or by external amino acid imbalance (Niederberger et al., 1981). Calculation of growth rates was based solely on turbidity measurements. Since turbidity is not linked to any particular cellular parameter, we monitored cell growth by measuring accumulation of dry weight and macromolecules, and cell division by measuring viable and total cell counts. We tested the influence of mutation $n d r l-l$ on these parameters under lysine, arginine and leucine limitation respectively, all induced by bradytrophic mutations of varying leakiness (Fig. 1). The strains were grown on MV-medium supplemented with the appropriate amino acids in amounts that led to their exhaustion during the exponential growth phase. In the bradytrophic strains, all cellular components were found to accumulate coordinately under amino acid limited growth, even though some lack of coordination was observed at the beginning (Fig. $1 a, c, e$ ). Under the influence of mutation $n d r l-1$, all cellular components still accumulated coordinately, but viable cell count clearly lagged behind (Fig. $1 b, d, f$ ). This could be interpreted in two ways: either the cells grew bigger or part of them lost their viability. In the leucine bradytrophic (leu \pm ) ndrl-1 double-mutant strain RH669, the decreasing viable cell count indicated loss in cell viability (Fig. $1 f$ ). For the other strains, discrimination between the two alternatives was possible only by monitoring both total and viable cell count. If cells grow bigger, the ratio between viable and total cell count should stay constant, whereas it should decrease upon cell death. Furthermore, the ratios between turbidity (established as a representative measure of cell growth, as shown in Fig. 1) and viable cell count should go in parallel with the ratio between turbidity and total cell count. In Fig. 2, these three ratios are plotted for the same strains as used in Fig. 1. As expected, the ratios remained relatively constant in the strains with an intact $N D R 1$ gene, even though some imbalance in the transient to amino acid limited growth was observed (Fig. 2a,c,e). Under the influence of mutation $n d r 1-1$, a permanent lack of coordination between cell growth and cell division became obvious (Fig. $2 b, d, f$ ). The ratio between turbidity and viable cell count always increased more than the ratio between turbidity and total cell count. The greater the amino acid 


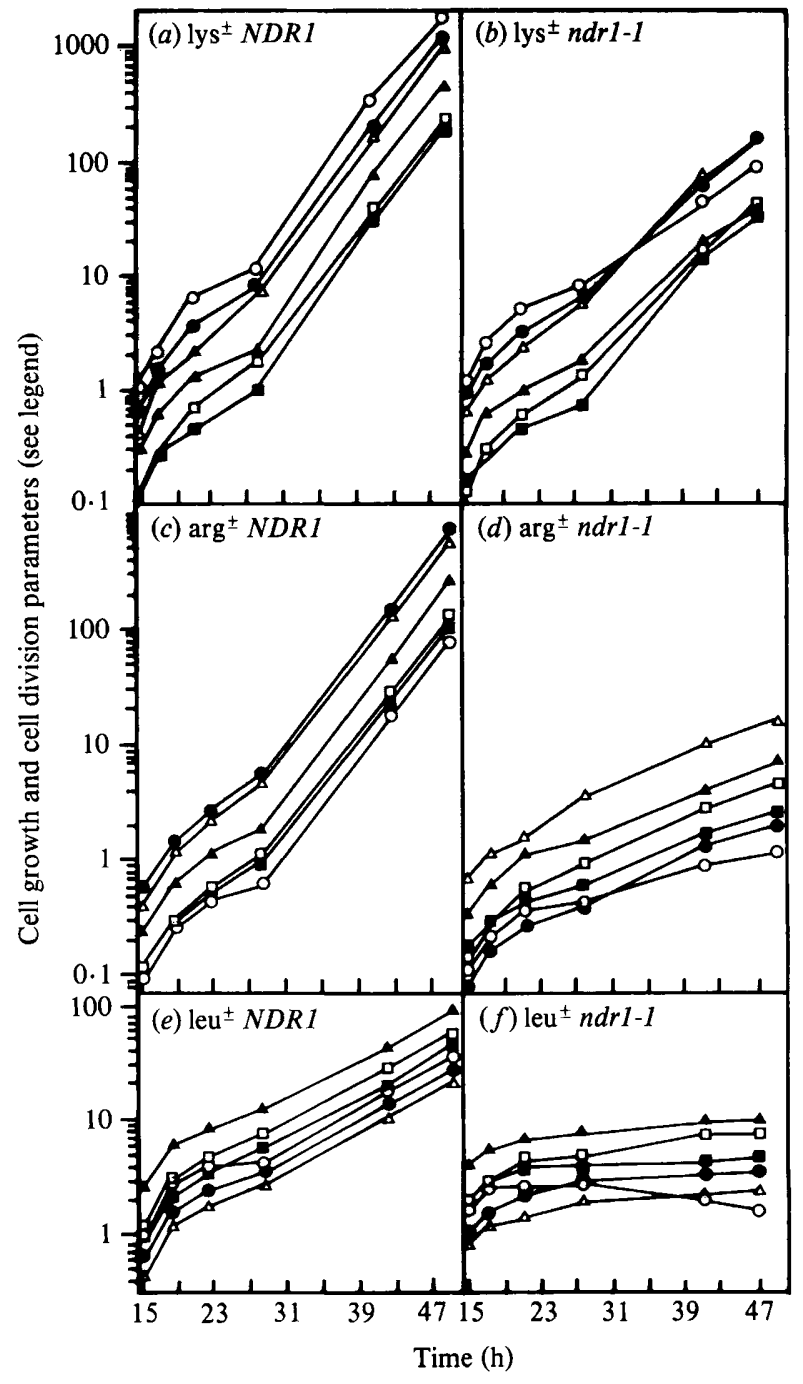

Fig. 1. Kinetics of growth of three bradytrophic $N D R 1$ and bradytrophic $n d r 1-1$ mutant strains in the transient to amino acid-limited growth. After pre-culturing the strains for $8 \mathrm{~h}$ in $\mathrm{MV}$-medium, supplemented with amino acids as indicated below, they were inoculated into identical media and grown for $15 \mathrm{~h}$ to a turbidity value of 0.6 to 0.9 (approx. $1.0 \times 10^{7}$ to $1.5 \times 10^{7}$ cells $\mathrm{ml}^{-1}$ ). (a) RH654 (lys ${ }^{ \pm}$); (b) RH737 (lys $\left.{ }^{ \pm} n d r l-1\right)$ supplemented with lysine $\left(15 \mu \mathrm{g} \mathrm{ml}^{-1}\right)$ and arginine $\left(50 \mu \mathrm{g} \mathrm{ml}^{-1}\right) ;(c)$ RH660 (arg \pm ); $(d)$ RH666 ( $\left.\arg ^{ \pm} n d r l-l\right)$ supplemented with arginine $\left(20 \mu \mathrm{g} \mathrm{ml}^{-1}\right)$; (e) RH657 (leu \pm ); (f) RH669 (leu \pm ndrI-l) supplemented with leucine $\left(15 \mu \mathrm{g} \mathrm{ml}^{-1}\right)$ and valine $\left(30 \mu \mathrm{g} \mathrm{ml}^{-1}\right)$. Subcultures were made for all strains (except for strain RH669) at $29 \mathrm{~h}$ into fresh MV-medium, to keep cells in exponential growth. All values for samples from these subcultures were corrected for the dilutions made. Turbidity at $546 \mathrm{~nm} ; \triangle$, protein $\left(10^{2} \times \mu \mathrm{g} \mathrm{ml}^{-1}\right) ; \square$, RNA $\left[10^{2} \times \mu \mathrm{g} \mathrm{ml}^{-1}\right.$ for $(a)$ to $(d)$ and $10 \times \mu \mathrm{g} \mathrm{ml}^{-1}$ for $(e)$ and $\left.(f)\right] ; \Delta$, DNA $\left[\mu \mathrm{g} \mathrm{ml}^{-1}\right.$ for $(a)$ to $(d)$ and $10^{-1} \times \mu \mathrm{g} \mathrm{ml}^{-1}$ for $(e)$ and $\left.(f)\right] ; \square$, dry weight $\left[10^{3} \times \mu \mathrm{g} \mathrm{ml}^{-1}\right.$ for $(a)$ to $(d)$ and $10^{2} \times \mu \mathrm{g} \mathrm{ml}^{-1}$ for $(e)$ and $\left.(f)\right] ; \bigcirc$, viable cell count $[\times$ $10^{7} \mathrm{ml}^{-1}$ for $(a),(b),(e)$ and $(f)$ and $\times 10^{8} \mathrm{ml}^{-1}$ for $(c)$ and $\left.(d)\right]$. Procedures for the determination of the different parameters are described in Methods.

limitation became (from Fig. $2 b$ to $d$ to $f$ ), the more pronounced was this difference. Accordingly, the ratio between viable and total cell count decreased. These data suggested that under slight limitations, $n d r l-1$ mutant cells grew bigger without substantial loss in cell viability, whereas under more severe limitation loss of cell viability became more important. 


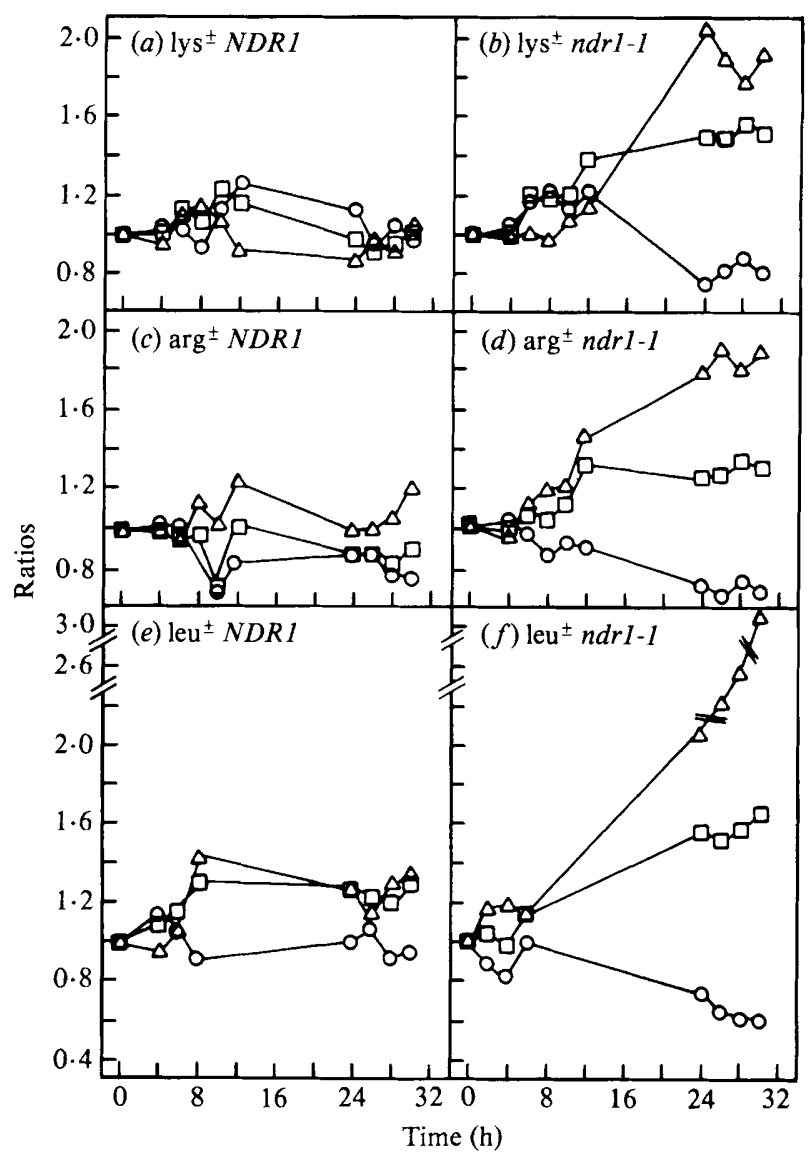

Fig. 2. Influence of mutation $n d r l-1$ on cell growth and viability of bradytrophic strains. Cells were cultivated as indicated in Fig. 1. The means of samples at three different time points starting about 4.5, 2.5 and $0.5 \mathrm{~h}$ before onset of amino acid limited growth, were taken to give the relative values of 1 at time zero. (a) RH654 (lys ${ }^{ \pm}$); (b) RH737 (lys ${ }^{ \pm} n d r l-1$ ); (c) RH660 (arg \pm ); (d) RH666 (arg ${ }^{ \pm} n d r l-1$ ); (e) RH657 (leu \pm ); $(f)$ RH669 (leu $\pm n d r l-1)$. $\bigcirc$, Ratio of viable to total cell count; $\triangle$, ratio of turbidity to viable cell count; $\square$, ratio of turbidity to total cell count.

Similar observations were also made under the influence of external amino acid imbalance. Earlier work showed that an excess of lysine leads to an arginine limitation, an excess of leucine to a valine limitation, and an excess tyrosine together with phenylalanine to a tryptophan limitation (Niederberger et al., 1981). Whereas the growth of wild-type (NDRI) cells was inhibited by only about $20 \%$, ndr $1-1$ mutant cells were inhibited by 70 to $80 \%$ by these amino acids. The amino acids lysine or leucine ( $2 \mathrm{mM}$ ), added to cells growing in minimal MV-medium, led to comparable increases in the ratios between turbidity and viable cell count and between turbidity and total cell count, i.e. the ratio between viable and total cell count stayed constant in strain RH375 (ndr1-1), whereas little change in either ratio was found in the wild-type strain (data not shown). This indicated an increase in cell size with little loss of cell viability for strain RH375 and essentially no effect on the wild-type strain. Addition of tyrosine and phenylalanine ( $2 \mathrm{mM}$ ) led to considerable loss of cell viability in strain RH375 (ndr1-1), whereas little effect was observed in the wild-type strain (Fig. $3 a, b$ ).

One shortcoming of the experiments presented so far is the fact that cells under the influence of mutation $n d r l-1$ were always more severely limited in growth, and thus no strict comparison between these and NDRI cells was possible. To investigate whether the effects observed were due solely to the more severe nutritional deprivation in $n d r l-1$ mutant cells, mutations not 


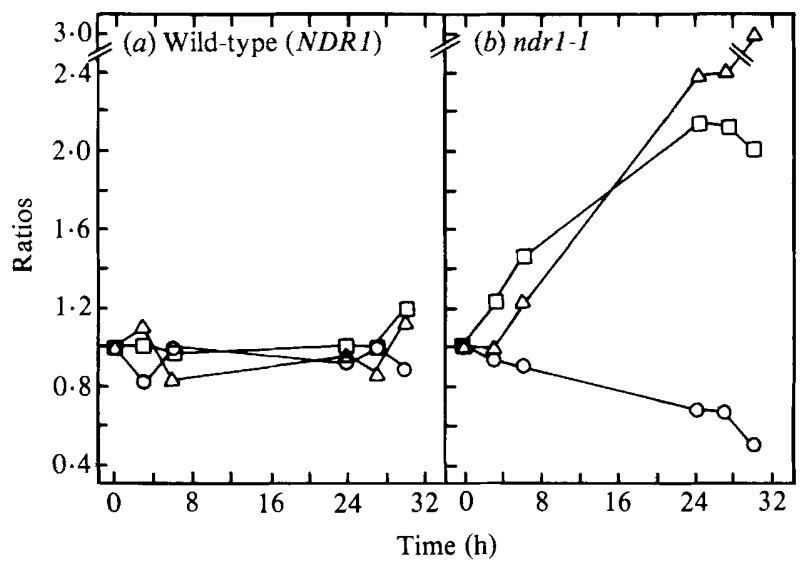

Fig. 3. Influence of mutation $n d r l-l$ on cell growth and viability under the influence of tyrosine and phenylalanine. Cells of $(a)$ the wild-type strain X2180-1 A, and $(b)$ the $n d r 1-1$ mutant strain RH375 were cultivated exponentially in MV-medium as indicated in Fig. 1. Means of samples at three different time points were taken to give the relative values of 1 at time zero. At this time, tyrosine and phenylalanine ( $2 \mathrm{~mm}$ each, final concentration) were added. $O$, Ratio of viable to total cell count; $\triangle$, ratio of turbidity to viable cell count; $\square$, ratio of turbidity to total cell count.

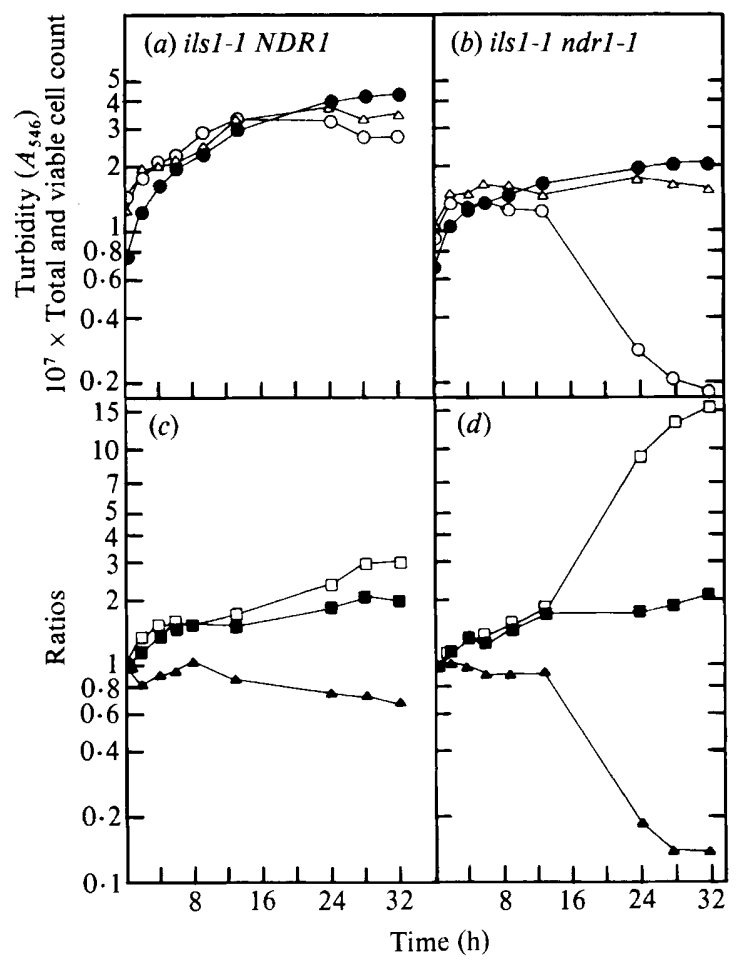

Fig. 4. Influence of mutation $n d r I-l$ on cell growth and cell division under limitation for charged tRNA ${ }^{1 l e}$. Exponentially growing cultures of strain RH700 (ilsl-1 NDRl) and RH701 (ils $1-1$ ndrl-l) were grown to a turbidity of 0.7 to 0.8 and then shifted to $34^{\circ} \mathrm{C}$. Turbidity $(O)$, viable cell count $(O)$ and total cell count $(\triangle)$ were monitored in $(a)$ strain RH700 and $(b)$ RH701. The corresponding ratios of viable to total cell count $(\mathbf{\Lambda})$, turbidity to viable cell count $(\square)$, and turbidity to total cell count ( $\square$ ) are plotted in $(c)$ and $(d)$. 
allowing any cell division in both backgrounds were used. Replacing the leucine bradytrophy (of unidentified nature) of strain RH657 by mutation leu2-2 led to a complete stop in cell division; nevertheless the influence on the ratios as plotted in Fig. $2(e, f)$ was essentially unchanged (data not shown for the leu2-2 ndrl-1 combination). As another example, strain RH700, carrying mutation ils $1-1$ (leading to a temperature-sensitive isoleucyl-tRNA synthetase, see McLaughlin et al., 1969), was used. A shift from $23{ }^{\circ} \mathrm{C}$ to $34^{\circ} \mathrm{C}$ led to a complete arrest of cell division (Fig. $4 a$ ). Mutation $n d r l-1$ led to a drastic decrease in cell viability within $32 \mathrm{~h}$ of limited growth (Fig. $4 b$ ). The corresponding ratios, as plotted in Fig. 4 ( $c$ and $d$ ) show a decreasing ratio between viable and total cell count in the $n d r l-1$ background. The ratios between turbidity and total cell count, however, increased similarly in the NDRl and $n d r 1-1$ backgrounds, indicating bigger cells in both cases.

\section{Cell size and cell morphology}

An increase in the ratio between turbidity and total cell count has been interpreted so far as an increase in cell size, with no information on cell morphology, however. Photomicrographs were thus taken of cells from the same strains as presented in Fig. 1, before and after $24 \mathrm{~h}$ of amino acid limited growth (Fig. 5). No obvious changes in cell morphology were observed in bradytrophic strains, except for strain RH657 (leu \pm ), in which cells grew bigger (Fig. $5 a, b, e, f, i$, $j$ ). Under the influence of mutation ndrl-1, however, a marked effect on cell size as well as cell morphology was found (Fig. $5 c, d, g, h, k, l$ ). Most interestingly, mutation $n d r l-l$ led to shmoolike cells under the weak lysine limitation, very similar to $\alpha$-factor-treated a cells (Fig. $5 d$; see Bücking-Throm et al., 1973). Microscopic examination showed that the percentage of shmooshaped cells was about $55 \%$, whereas the other cells looked apparently normal (data not shown). Under arginine limitation, elongated buds (Fig. $5 h$ ) (in about $40 \%$ of the cells) were observed, and under the strong leucine limitation, bigger cells of regular shape were seen (Fig. $5 j$ and $l$ ).

Other amino acid limitations, induced by serine or histidine bradytrophic mutations, respectively, combined with mutation ndrl-1 (see Niederberger et al., 1981) led to cells with elongated buds, similar to those observed under an arginine limitation (data not shown). Mutations leu2-2 and ils $1-1$ led to bigger cells in both an ndrl-1 and an NDRI background as shown in Fig. 5( $j$ and $l)$. This observation confirmed the indirect evidence for a cell-size increase as deduced from the ratio between turbidity and total cell count (see above).

\section{Why do ndrl-1 mutant cells lose their viability?}

The basic difference originally observed between wild-type (NDR-l) and ndrl-I mutant cells was the loss of the ability to derepress enzymes under the general control (Schürch et al., 1974). It was known, however, from earlier reports, that derepression in $N D R l$ cells occurred only under partial amino acid deficiency, e.g. in bradytrophic strains. Strictly auxotrophic strains did not show an enzyme derepression (Wolfner et al., 1975; and unpublished data from this laboratory). Strains and conditons were thus chosen where the dependence of viability on enzyme derepression could be compared under partial limitation and complete starvation. Strains RH657 (leu \pm ) and RH761 (leu2-2) on the one hand, and strain RH700 (ils1-1) at semipermissive $\left(34^{\circ} \mathrm{C}\right)$ and non-permissive $\left(37^{\circ} \mathrm{C}\right)$ temperature, respectively, on the other, provided such conditions. In addition, the influence of mutation $n d r l-1$ was tested. Strains RH657 and RH761 were shifted to MV-medium, and derepression of indole-3-glycerol-phosphate synthase (a tryptophan biosynthetic enzyme subject to the general control; see Schürch et al., 1974; Niederberger et al., 1981) was measured after 2, 6 and $24 \mathrm{~h}$, respectively (Fig. $6 a$ and $b$ ). Whereas the relative specific activity in strain RH657 increased $2 \cdot 5$-fold over $6 \mathrm{~h}$, no derepression occurred in strain RH761. In the corresponding $n d r 1-1$ double-mutant strains, the activity was found to be considerably decreased. Essentially the same trends for the enzyme levels were also observed for several other amino acid biosynthetic enzymes subject to the general control (data not shown). Both strains, RH657 and RH761, did not show significantly decreased cell viability, whereas their corresponding $n d r l-1$ double-mutant strains lost viability at comparable rates [Fig. 2; data not shown for strains RH761 (leu2-2) and RH781 (leu2-2 $n d r l-1)]$. 

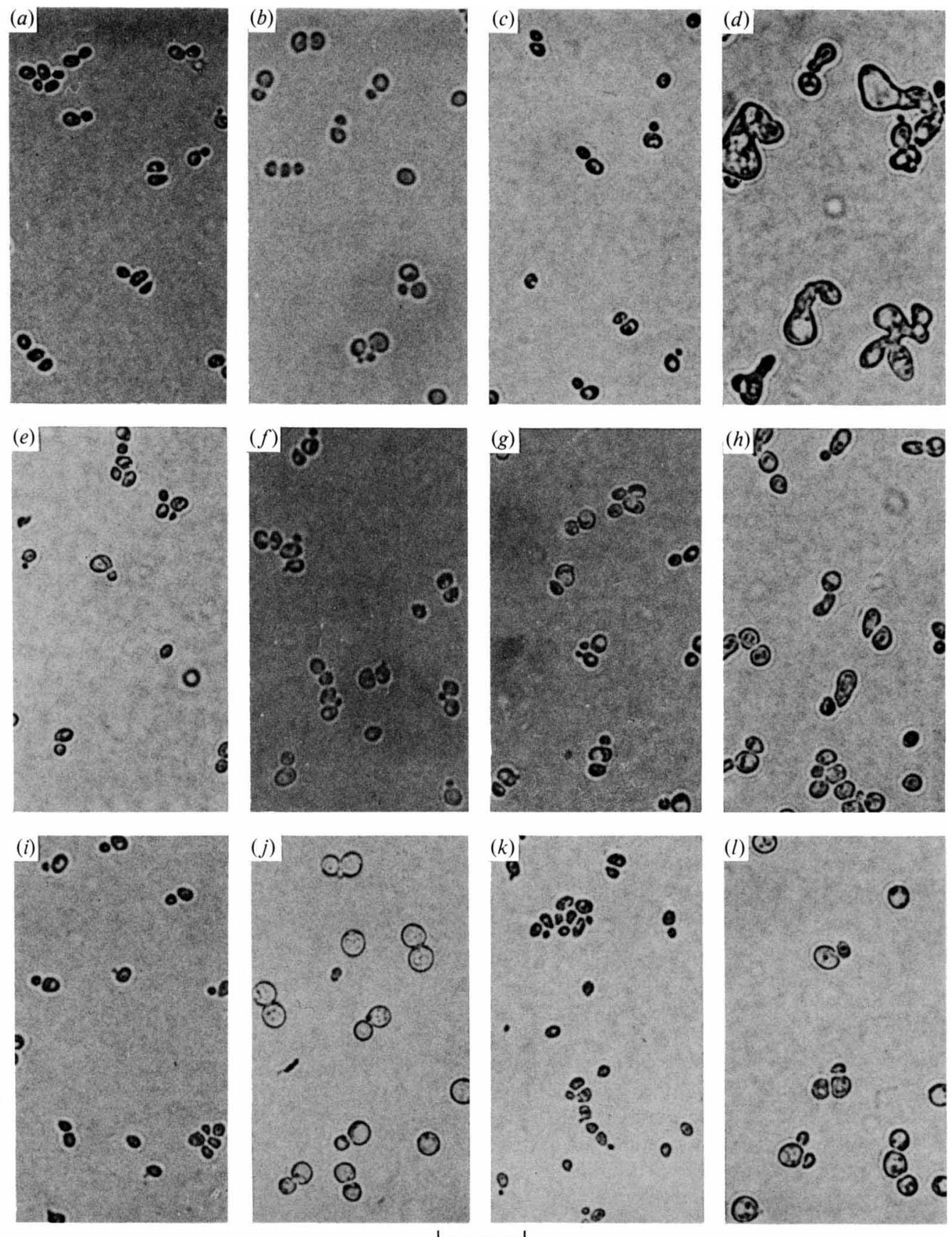

Fig. 5. Influence of mutation $n d r l-1$ on cell morphology in bradytrophic strains. The strains were cultivated as indicated in Fig. 1. Photomicrographs of the cells were taken at time zero and after $24 \mathrm{~h}$ of amino acid limited growth, respectively: $(a$ and $b)$ RH654 (lys $\left.{ }^{ \pm}\right)$; $(c$ and $d)$ RH737 (lys $\left.\pm n d r 1-1\right)$; $(e$ and $f)$ RH660 $\left(\arg ^{ \pm}\right) ;(g$ and $h)$ RH666 $\left(\arg ^{ \pm} n d r l-1\right)$; $(i$ and $j)$ RH657 (leu $\left.{ }^{ \pm}\right) ;(k$ and $l)$ RH669 (leu ${ }^{ \pm}$ $n d r l-1)$. The bar marker represents $20 \mu \mathrm{m}$. 


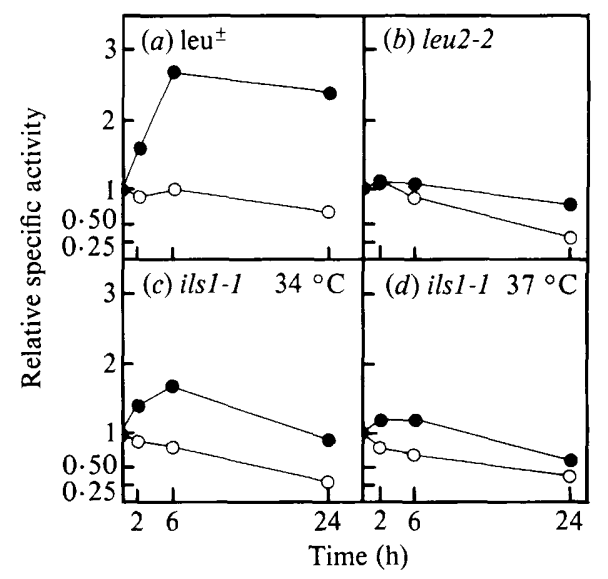

Fig. 6. Influence of mutation $n d r 1-1$ on the regulation of indole-3-glycerol-phosphate synthase. Cells of strains (a) RH657 (leu ${ }^{ \pm}$) and RH669 (leu \pm ndr1-1), (b) RH761 (leu2-2) and RH781 (leu2-2 ndr1-1), and ( $c$ and $d$ ) RH700 (ils $1-I$ ) and RH701 (ils $1-1$ ndrl-1) were cultivated under non-limiting conditions by either supplementing $\mathrm{MV}$-medium with leucine $\left(50 \mu \mathrm{g} \mathrm{ml}^{-1}\right)$ and valine $\left(50 \mu \mathrm{g} \mathrm{ml}^{-1}\right)$ (leu \pm and leu2-2 strains) or growing cells at $23^{\circ} \mathrm{C}$ (ils $1-1$ strains). At time zero, the first samples were harvested and cultures then put under limiting conditions by either filtering off cells and resuspending them in $\mathrm{MV}$ medium or by shifting them to $(c) 34^{\circ} \mathrm{C}$ and $(d) 37^{\circ} \mathrm{C}$, respectively. The level of indole-3-glycerolphosphate synthase was determined at the time points indicated. Absolute values [nmol min ${ }^{-1}$ (mg protein) ${ }^{-1}$ ] set as $1:$ leu ${ }^{ \pm} 1 \cdot 2$, leu ${ }^{ \pm}$ndr $1-10 \cdot 9$, leu2-2 $1 \cdot 3$, leu2-2 ndr $1-10 \cdot 9$, ils $1-11 \cdot 6$, ils $1-1$ ndrl-1 $1 \cdot 1$. Strains in NDRI background; $O$, strains in $n d r l-1$ background.

A similar situation was observed with strain RH700 (ils1-1) (Fig. 6c, d). A transitory derepression occurred only upon shift to $34^{\circ} \mathrm{C}$, but not upon shift to $37^{\circ} \mathrm{C}$. On shifting to either temperature, strain RH701 (ils $1-1$ ndrl-1) displayed markedly decreased enzyme levels, while strain RH700, irrespective of the shift temperature, largely kept its viability; the viable cell count of strain RH701 dropped at comparable rates upon shifting to either temperature (Fig 4; data not shown for shift to $37^{\circ} \mathrm{C}$ ).

In conclusion, no correlation between cell viability and derepression of enzymes under the general control became obvious in wild-type $(N D R I)$ cells; even under strict amino acid starvation conditions, viability was largely maintained. It is likely, however, that these $N D R I$ cells maintained significantly higher enzyme levels than ndrl-1 mutant cells; the latter, besides having slightly lower absolute enzyme levels before the onset of amino acid limitation (see legend to Fig. 6), showed a further marked decrease under amino acid limited growth (Fig. 6).

Another reason for the loss of viability in ndrl-1 mutant cells could be their inability to accumulate at Start. Two sets of experiments were done to test this: first, strains $\mathrm{RH} 700$ (ils1-1 NDRI) and RH701 (ils1-1 ndr1-1) were shifted to $34^{\circ} \mathrm{C}$ and $37^{\circ} \mathrm{C}$, respectively, and secondly, wild-type (NDRI) and ndrl-1 mutant cells were starved for the basic nutrients ammonia or glucose. In both cases accumulation at Start was monitored by counting the percentage of unbudded cells.

Cells of the wild-type strain RH700 (ils 1-1 NDRl) were found to accumulate in the unbudded state upon shift to $34^{\circ} \mathrm{C}$ as well as to $37^{\circ} \mathrm{C}$ (Fig. $7 a$ ), whereas cells of strain RH701 (ils-1 ndrl-I) did so only upon shift to $34^{\circ} \mathrm{C}$ (Fig. 7 b). As mentioned above, cells of strain RH701 lost their viability at comparable rates upon shift to both temperatures. This showed that $n d r 1-1$ mutant cells were able in principle to accumulate in the unbudded state but could not draw an obvious advantage for survival out of this.

Starvation for ammonia or glucose led to complete accumulation at Start in both NDR1 and $n d r 1-1$ backgrounds. No detrimental effect of mutation $n d r l-1$ on cell viability was found under these conditions (data not shown). This showed again that mutation $n d r l-l$ did not influence in principle the ability to accumulate at Start, and further that the general control was not relevant 


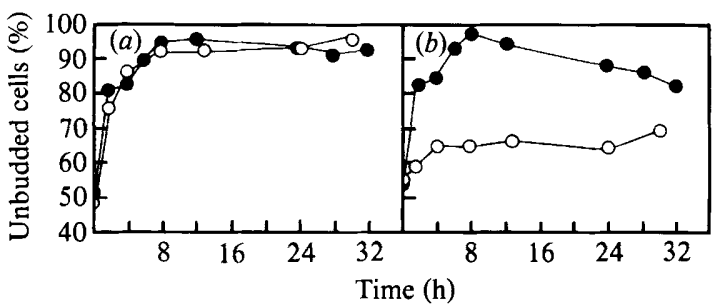

Fig. 7. Influence of mutation $n d r l-I$ on proportion of unbudded cells under limitation for charged isoleucyl-tRNA. Cells of strain RH700 (ils $1-1$; 0 ) and RH701 (ils $1-1$ ndr $1-1$; O) were grown at the permissive temperature to a turbidity of about 1 and then shifted to $(a) 34^{\circ} \mathrm{C}$ and $(b) 37^{\circ} \mathrm{C}$, respectively. Unbudded cells were scored as indicated in Methods.

under starvation for basic nutrients such as ammonia or glucose. The question arose, however, whether cells under limitations for amino acids (or charged tRNA) would reach the same or a different status before Start as under limitation for ammonia. This was tested in a reciprocal shift experiment.

Cells of strains RH700 (ils1-1 NDRI) and RH701 (ils1-1 ndr1-1) were first deprived of ammonia until they accumulated completely in the unbudded state, and were then shifted to $34^{\circ} \mathrm{C}$ and vice versa (Fig. 8). When cells of both strains were deprived of ammonia at $23^{\circ} \mathrm{C}$ first, they both accumulated readily in the unbudded state after about 1.5 doublings (Fig. $8 a$ and $c$ ). When they were shifted to $34^{\circ} \mathrm{C}$ after $8 \mathrm{~h}$, they did not enter a new round of mitotic division, even though ammonia was added. Under these conditions, mutations $n d r l-1$ had no detrimental effect on viability. When cells of both strains were shifted to $34{ }^{\circ} \mathrm{C}$ first, they accumulated in the unbudded state, again after about 1.5 doublings (Fig. $8 b$ and $d$ ). When they were shifted back to $23{ }^{\circ} \mathrm{C}$, after the ammonia had been removed from the medium, both strains underwent about two rounds of cell division before they accumulated in the unbudded state again.

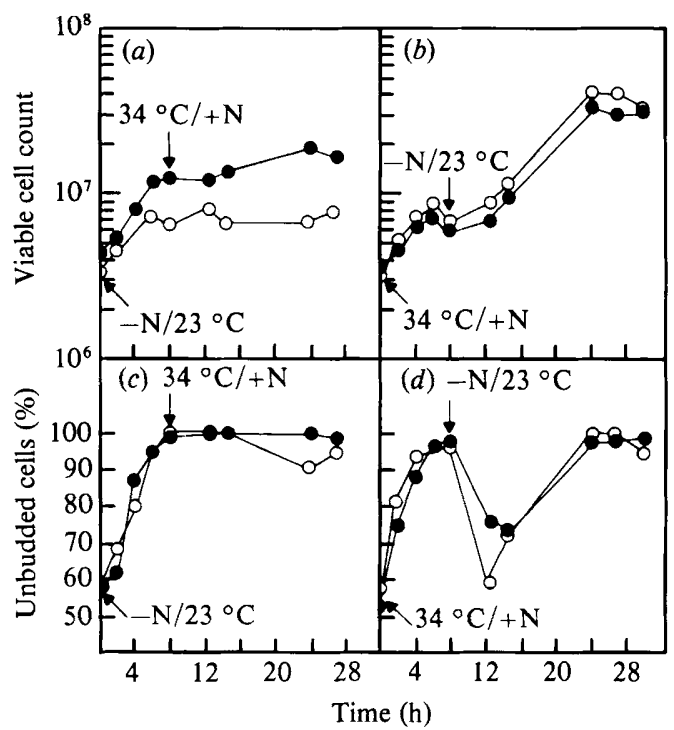

Fig. 8. Reciprocal shift experiment with strains RH700 (ilsl-I NDRI) and RH701 (ilsl-1 ndrl-1). Cells of strain RH700 (ils1-1 NDR1; ) and strain RH701 (ils1-1 ndr1-1; O) were cultivated in MV-medium at $23{ }^{\circ} \mathrm{C}$ to a turbidity of $0 \cdot 8$. The cultures were then divided into two samples. The first $(a$ and $c)$ was filtered, the cells washed with $50 \mathrm{ml}$ distilled water, and then resuspended in the same volume of MVmedium lacking ammonium sulphate. The other sample $(b$ and $d)$ was shifted to $34^{\circ} \mathrm{C}$. Cultivation was continued for $8 \mathrm{~h}$ under these conditions, before the first sample was shifted to $34^{\circ} \mathrm{C}$, and 30 min later ammonium sulphate was added $[0.525 \%(\mathrm{w} / \mathrm{v})$ final concentration]; cells of the second sample were filtered, washed and resuspended in MV-medium, and $30 \mathrm{~min}$ later they were shifted back to $23^{\circ} \mathrm{C}$. Determination of viable cell count and degree of budding was as described in Methods. 
Are the different phenotypes due to one mutation only?

$\mathrm{Ndr}$-mutant strains were isolated on the basis of their sensitivity against the tryptophan analogue 5-methyltryptophan (Schürch et al., 1974). This original phenotype was correlated with the 'non-derepressibility' of enzymes under the general control of amino acid biosynthesis (Miozzari et al., 1978a; Niederberger et al., 1981). The experiments presented above show up two additional phenotypes: lack of coordination of cell growth with cell division and decreased cell viability. We wanted to demonstrate that these phenotypes are all due to mutation $n d r 1-1$.

In the first case, co-segregation of mutation ndrI-1 (identified by its 5-methyltryptophan sensitivity) with the shmoo phenotype in the presence of the lysine bradytrophy of strain RH654 was tested. In a backcross analysis of strain RH654 with strain RH375 (ndr1-1), 432 random segregant clones were tested. Of 208 segregants carrying the $n d r 1-1$ mutation, 109 were found to form shmoo-cells on MV-medium. All of these were identified as lysine bradytrophic ndrI-I double-mutant strains. The remaining 99 segregants produced no shmoo-cells and did not carry the lysine bradytrophy. The 224 segregants not carrying mutation $n d r l-1$ did not produce shmoocells either.

In the second case, co-segregation of mutation $n d r 1-1$ with the loss of cell viability in the presence of mutation ilsl-1 was tested. This co-segregation was confirmed in 15 tetrads of a backcross between strain RH701 (ils1-1 ndrl-1) and the wild-type strain X2180-1A (data not shown).

We tested further the influence of mutations $n d r 1-2$ (strain RH428), ndr2-1 (strain RH487) and aas2 (strain 4298-9C, see Wolfner et al., 1975) in combination with the same bradytrophic mutations as presented in Fig. 1 as well as in combination with mutation ils $1-1$. They all led either to the same aberrant cell morphologies or to accelerated loss of cell viability as found in combination with mutation $n d r l-1$ (data not shown).

\section{DISCUSSION}

\section{Function of the general control in the maintenance of cell viability}

The significance of a derepression of amino acid biosynthetic enzymes subject to the general control is still poorly understood. Several observations led to a puzzling picture of this regulatory system. First, most enzymes under the general control are not repressed by the corresponding amino acid and thus have abundant synthetic capacity (Hilger et al., 1973; Miozzari et al., 1978a). Second, derepression is non-coordinate, that is, under amino acid limitations, as induced by analogues or bradytrophic mutations, the degree of derepression varies from enzyme to enzyme and only some of the enzymes of a pathway are elevated (e.g. only four of the five tryptophan, and one of the three leucine biosynthetic enzymes are derepressed, see Miozzari et al., 1978a; Hsu et al., 1982). Third, this non-coordinate derepression becomes negligible under amino acid limitations, when induced by external amino acid imbalance (Niederberger et al., 1981).

The data presented here, however, show a significant difference in enzyme levels between wild-type (NDRI) and $n d r l-1$ mutant cells under amino acid limitation. Whereas $N D R I$ cells under all limitations were able to maintain at least the enzyme levels of non-limited growth conditions, these levels fell considerably in $n d r 1-1$ mutant cells under amino acid limitations, irrespective of how strong the limitations were and of how they were induced (Fig. 6 and Niederberger et al., 1981).

The function of the general control thus may be seen in the maintenance of adequately high (but not necessarily elevated) levels of amino acid biosynthetic enzymes, and this seems to be crucial for survival.

\section{The difference between limitation for basic nutrients and amino acids}

Cells starved for basic nutrients such as carbon, nitrogen, sulphur or phosphorus sources accumulate at Start (Unger \& Hartwell, 1976; Johnston et al., 1977). Ammonia-starved cells have been found to grow considerably smaller before they finally stop cell division (Johnston $e t$ al., 1977). The arrest at Start under such a nutritional limitation may be explained simply by the 
fact that such cells have not reached a critical size (Hartwell \& Unger, 1977; Carter \& Jagadish, 1978; Tyson et al., 1979). The general control does not interfere with this basic mechanism, since ndrI-I mutant cells accumulated at Start perfectly well under starvation for such basic nutrients.

Cells under amino acid limitations (or limitations for charged tRNA) appear to be able to accumulate at Start as well, provided this limitation is not introduced too abruptly (Unger \& Hartwell, 1976). Some auxotrophic mutations not allowing accumulation at Start may be considered as unphysiological in this respect. Yeast cells would hardly encounter such complete deprival of an amino acid in nature, but instead would encounter rather mild limitation like those occurring under external amino acid imbalance (Niederberger et al., 1981). Our experiments, however, in which wild-type $(N D R l)$ cells were subject to severe limitations under the influence of mutations leu2-2 or ils $1-1$, showed a different effect on cell growth as compared with basic nutrients: upon accumulation at Start, they tended to grow bigger rather than smaller.

The major problem of cells accumulating at Start under amino acid limitation thus seems to be to curtail cell growth. In this situation, excessive cell growth would be prevented only by the initiation of a new cell division cycle. Indeed Shilo et al. (1978) produced evidence that the rate of cycle initiation is more sensitive to amino acid limitation than overall protein synthesis. They postulated a 'metabolic intermediate', most likely a protein or subunits of a protein, to be involved in the monitoring of the nutritional status. $N d r l-1$ mutant cells, especially under mild amino acid limitations, may have curtailed the synthesis of this particular protein much more than overall protein synthesis (or alternatively have a higher decay rate of this protein), which would result in the excessive cell growth observed.

The reciprocal shift experiments illustrate the difference between limitation for ammonia and amino acids: if starved for ammonia first, cells are too small to initiate a new cycle; if starved first for charged tRNA ${ }^{\text {lle }}$ they are big enough and may initiate a new cycle. In the second case, they have most likely stored enough nitrogen compounds (mainly glutamine) inside the cells to traverse more than one further cell cycle, even though all the ammonia had been removed from the medium.

The loss of cell viability of $n d r 1-1$ mutant cells under strong amino acid limitations has been shown to be independent of an accumulation at Start; thus it is not linked to a particular time in the mitotic cell cycle, and can be explained by the failure to maintain adequately high levels of amino acid biosynthetic enzyme (see preceding paragraph).

\section{A comparison between ndr1-I mutant cells and transformed malignant cells}

It may be interesting to compare $n d r l-1$ mutant cells with some transformed, malignant higher eukaryotic cells. Such cells continue to grow at sub-optimal nutrient concentration, under which normal cells stop growing (Holley, 1975). Furthermore, transformed cells were reported to lose viability upon limitation for isoleucine or glutamine much faster than normal cells (Pardee, 1974). The very similar behaviour of yeast $n d r$-mutant cells and transformed higher eukaryotic cells under amino acid limiting conditions is striking.

We thank Monique Herensperger and Annemarie Schmuckle for skilful technical assistance. This work was supported by the Swiss National Foundation for Scientific Research, project 3.262-0.78.

\section{REFERENCES}

Amerine, M. A. \& Ough, C. S. (1980). Methods for Analysis of Musts and Wines, p. 154. New York \& London: Wiley.

Bestic, P. B. \& ARnold, W. N. (1976). Linear transformation of standard curves for yeast turbidity. Applied and Environmental Microbiology 32, 640-641.

BRENNER, M. \& AMES, B. N. (1971). The histidine operon and its regulation. In Metabolic Pathways, vol. 5, Metabolic Regulation, 3rd edn, pp. 349-387. Edited by H. J. Vogel. London: Academic Press.
Bücking-Throm, E., Duntze, W., Hartwell, L. H. \& MANnEY, T. R. (1973). Reversible arrest of haploid yeast cells at the initiation of DNA synthesis by a diffusible sex factor. Experimental Cell Research 76, 99-110.

Carsiotis, M. \& Jones, R. F. (1974). Cross pathways regulation: tryptophan mediated control of histidine and arginine biosynthetic enzymes in Neurospora crassa. Journal of Bacteriology 119, 889-892.

Carter, B. L. A. \& Jagadish, M. N. (1978). The 
relation between cell size and cell division in the yeast Saccharomyces cerevisiae. Experimental Cell Research 112, 15-23.

Delforge, J., Messenguy, F. \& Wiame, J. M. (1975). The regulation of arginine biosynthesis in Saccharomyces cerevisiae. The specificity of $\arg \mathrm{R}^{-}-$mutations and the general control of amino acid biosynthesis. European Journal of Biochemistry 57, 231-239.

Fowell, R. R. (1966). Hybridization of yeast. Process Biochemistry 1, 25-28.

HaRTWEll, L. H. \& UNGER, M. V. (1977). Unequal division in Saccharomyces cerevisiae and its implications for the control of cell division. Journal of Cell Biology 75, 422-235.

Herbert, D., Phipps, P. J. \& Strange, R. E. (1971). Chemical analysis of microbial cells. Methods in Microbiology 5B, 209-344.

Hilger, F., Culot, M., Minet, M., Pierard, A., Grenson, M. \& Wiame, J. M. (1973). Studies on the kinetics of the enzyme sequence mediating arginine synthesis in Saccharomyces cerevisiae. Journal of General Microbiology 75, 33-41.

Holley, R. W. (1975). Control of growth of mammalian cells in cell culture. Nature, London 258, 487490.

Hsu, Y.-P., Kohlhaw, G. B. \& Niederberger, P. (1982). Evidence that $\alpha$-isopropylmalate synthase of Saccharomyces cerevisiae is under the 'general' control of amino acid biosynthesis. Journal of Bacteriology 150, 969-972.

Johnston, G. C., Pringle, J. R. \& Hartwell, L. H. (1977). Coordination of growth with cell division in the yeast Saccharomyces cerevisiae. Experimental Cell Research 105, 79-98.

Johnston, J. R. \& Mortimer, R. K. (1959). Use of snail digestive juice in isolation of yeast spore tetrads. Journal of Bacteriology 78, 292.

Mclaughlin, C. S., Magee, P. T.\& Hartwell, L. H. (1969). Role of isoleucyl-transfer ribonucleic acid synthetase in ribonucleic acid synthesis and enzyme repression in yeast. Journal of Bacteriology 100, 579 584.

Miozzari, G., Niederberger, P. \& Hütter, R. (1978a). Tryptophan biosynthesis in Saccharomyces cerevisiae: control of the flux through the pathway. Journal of Bacteriology 134, 48-59.
Miozzari, G., Niederberger, P. \& Hütter, R. $(1978 b)$. Permeabilization of microorganisms by Triton X-100. Analytical Biochemistry 90, 220-223.

Niederberger, P., Miozzari, G. \& Hütter, R. (1981). Biological role of the general control of amino acid biosynthesis in Saccharomyces cerevisiae. Molecular and Cellular Biology 1, 584-593.

PARDEe, A. B. (1974). A restriction point for control of normal animal cell proliferation. Proceedings of the National Academy of Sciences of the United States of America 71, 1286-1290.

PIOTROwsKA, M. (1980). Cross-pathway regulation of ornithine carbamoyltransferase synthesis in Aspergillus nidulans. Journal of General Microbiology 116, 335-339.

Pringle, J. \& HaRtwell, L. H. (1981). The Saccharomyces cerevisiae cell cycle. In The Molecular Biology of the Yeast Saccharomyces, pp. 97-142. Edited by J. N. Strathern, E. W. Jones \& J. R. Broach. Cold Spring Harbor, New York: Cold Spring Harbor Laboratory.

Schürch, A., Miozzari, J. \& HütTER, R. (1974). Regulation of tryptophan biosynthesis in Saccharomyces cerevisiae: mode of action of 5-methyltryptophan and 5-methyl-tryptophan-sensitive mutants. Journal of Bacteriology 117, 1131-1140.

Shilo, B., Simchen, G. \& Pardee, A. B. (1978). Regulation of cell-cycle initiation in yeast by nutrients and protein synthesis. Journal of Cell Physiology 97, 177-187.

STEWART, P. R. (1975). Analytical methods in yeasts. Methods in Cell Biology 12, 111-147.

Tyson, C. B., LoRd, P. G. \& Wheals, A. E. (1979). Dependency of size of Saccharomyces cerevisiae cells on growth rate. Journal of Bacteriology 138, 92-98.

UNGER, M. V. \& Hartwell, L. H. (1976). Control of cell division in Saccharomyces cerevisiae by methionyl-tRNA. Proceedings of the National Academy of Sciences of the United States of America 73, 1664 1668.

Wolfner, M., YeP, D., Messenguy, F. \& Fink, G. R. (1975). Integration of amino acid biosynthesis into the cell cycle of Saccharomyces cerevisiae. Journal of Molecular Biology 90, 273-290. 